\title{
PERCERAIAN ORANG TUA DAN IMPLIKASINYA TERHADAP PENDIDIKAN ANAK DALAM ISLAM
}

\author{
Rima Hadayati \\ Sekolah Tinggi Ilmu Tarbiyah Raudhatul Ulum, Sakatiga \\ Email: rimahadayati2015@gmail.com
}

\begin{abstract}
Abstrak
Every child is born in a state of nature, then both his parents who make it Jewish, or Zoroastrian Nashrani (HR.Muslim). Implied meaning of the hadith is that the formation of the child's personality is influenced by upbringing and education of parents. Basically every child wants to live with his parents, didikik, nurtured and given affection filled by both parents. However, if the household of his parents could not be maintained in this case happens disharmony or other factors so that his parents divorced, the children are victims of divorce of their parents. Divorce for children is "a sign of the death of" the unity of the family, it was half of the "self" has lost a child, life will never be the same again after their parents divorced and they have to accept the grief and sense of loss is profound. such children should harbored a deep sense of longing for a father or mother who suddenly does not live with him anymore. The negative effect of divorce on the development and education of children are: children get less attention, affection, and educational demands of parents, the need for physical and psychological teen is not consummated, the children do not get physical exercise and mental indispensable for moral life, divorce of parents expected to affect the learning achievement of children, both in the field of religious studies as well as in other fields, improve the delinquency of children, influence the formation of the child's personality.
\end{abstract}

Keyword: Divorce, Parents, Child Education, Islam

\section{Pengertian Perceraian}

Suatu perkawinan dimaksudkan untuk menciptakan kehidupan suami isteri yang harmonis dalam rangka membentuk dan membina keluarga yang sejahter dan bahagia di sepanjang masa. Dalam hubungan sebuah rumah tangga antara suami isteri selalu mendambakan agar ikatan lahir batin yang berdasarkan dengan akad perkawinan itu semakin kokoh terpateri sepanjang hayat masih dikandung badan.

Islam telah mengatur sedemikian rupa hubungan suami isteri agar rumah tangga yang penuh dengan mawaddah wa rahmahNamun demikian kenyataan hidup membuktikan bahwa memelihara kelestarian dan kesinambungan hidup bersama suami isteri itu bukanlah perkara yang mudah dilaksanakan, bahkan dalam banyak hal kasih sayang dan kehidupan yang harmonis antara suami isteri itu tidak dapat diwujudkan. Faktor-faktor psikologi, biologis, ekonomi, perbedaan kecenderungan, pandangan hidup, sering mencul dalam kehidupan rumah tangga bahkan dapat menimbulkan krisi rumah tangga.Perceraian dalam istilah fiqh disebut talak atau furqah, kata talak berarti 


\section{Perceraian Orang Tua dan Implikasinya Terhadap Pendidikan Anak Dalam Islam Rima Hadayati}

membuka ikatan, membatalkan perjanjian, sedangkah furqah berarati bercerai, dalam istilah fiqh diartikan sebagai perceraian antara suami atau istri.

Menurut hukum Islam perceraian berarti;

a. Menghilangkan ikatan perkawinan atau mengurangi keterikatan dengan ucapan tertentu

b. Melepaskan ikatan perkawinan dan mengakhiri hubungan suami isteri

c. Melepaskan ikatan akad perkawinan dengan ucapan talak atau yang sepadan dengannya. ${ }^{1}$

Sedangkan perceraian menurut Kompilasi Hukum Islam (KHI) pasal 117 perceraian adalah ikrar suami dihadapan sidang Pengadilan Agama yang menjadi salah satu sebab putusnya perkawinan. ${ }^{2}$ Berdasarkan uraian tersebut dapat diperoleh pemahaman bahwa perceraian adalah putusnya ikatan perkawinan antara suami dan isteri yang sah dengan mengunakan lafadz talak atau semisalnya, selanjutya dipertegas oleh ketentuan Pasal 38 Undang-undang No.1 Tahun 1974 tentang perkawinan, bahwa perkawinan dapat putus disebabkan karena kematian, perceraian dan putusan Pengadilan, yang mana akibat hukum yang ditimbulkan dari jalan keluar lain lagi kecuali ketiga sebab tersebut berbeda-beda.

Perceraian merupkan jalan terakhir apabila anatara suami isteri sudah mencoba untuk ikhtiar dan segala daya telah dilakukan untuk memperbaiki kehidupan perkawinan yang ternyata tidak ada jalan keluar lain kecuali dengan perceraian. Perceraian merupakan hal yang halal akan tetapi di benci oleh Allah SWT.

\section{Alasan Perceraian}

Alasan perceraian menurut Undang-undang No.1 Tahun 1974 pasal 19, sebagai berikut:

1. Salah satu pihak berbuat zina atau menjadi pemabuk, pemadat, penjudi dan lain sebagainya yang sukar disembuhkan;

2. Salah satu pihak meningalkan pihak lain 2 (dua0 tahun berturut-turut tanpa izin pihak lain dan tanpa lasan yang sah atau karena hal lain diluar kemampuannya;

3. Salah satu pihak mendapat hukuman penjara 5 (lima) tahun atau hukuman yang lebih berat setelah perkawinan berlangsung;

4. Salah satu pihak melakukan kekejaman atau menganiayaan berat yang membahayakan pihak lain;

5. Salah satu pihak mendapat cacat badan atau penyekit dengan akibat tidak dapat menjalankan kewajiban sebagai suami isteri

6. Antara suami isteri terus menerus terjadi perselisihan dan pertengkaran dan tidak ada harapan untuk akan hidup rukun lagi dalam rumah tangga. ${ }^{3}$

\footnotetext{
${ }^{1}$ Zahri Hamid. Pokok-pokok Hukum Perkawinan Islam dan Undang-undang Perkawinan Indonesia, (Yogyakarta: Bina Cipta, 1976), h.5.

${ }^{2}$ Kompilasi Hukum Islam, Pasal 117

${ }^{3}$ Undang-undang No.1 Tahun 1974 Tentang Perkawinan, Pasal 19.
} 
Dalam Kompilasi Hukum Islam (KHI), disamping yang telah disebutkan diatas diatas ditambah dua alasan lagi seperti yang termuat dalam Pasal 116 poin $g$ dan $h$, sebagai berikut: g). suami melanggar taklik-talak dan h. Peralihan agama atau murtad yang menyebabkan terjadi ketidakrukunan dalam rumah tangga ${ }^{4}$ Selain alasan perceraian diatas, menurut Hisako Nakamura dalam bukunya yang berjudul "Perceraian Orang Jawa" percerain terjadi karena

1) Ekonomi, yang menunjukan suami tidak mampu untuk menghidupi isteri dan keluarganya

2) Krisis Moril, yaitu keadaan suami isteri yang mengadakan hubungan seksual dengan orang lain yang bukan pasangan yang sah, seperti berbuat serong.

3) Dimadu, yaitu dalam dua bentuk keadaan: (a) isteri sudah dimadu dengan isteri lain (seseorang atau lebih) dan ia merasa tidak tahan lagi. (b) suami ingin kawin lagi sedang istri tidak mau dimadu.

4) Meningalakan kewajiban suami atas isterinya atau sebaliknya antara isteri dan suaminya.

5) Biologis, adalah keadaan suami yang tidak mempunyai kemampuan jasmani untuk membina perkawinan yang bahagia seperti sakit impotent atau mandul

6) Pihak ketiga, yaitu campur tangan dari pihak lain seperti orang tua dan isteri atau suami dalam urusan rumah tangga.

7) Politik, yaitu pertentangan keyakinan politik antara suami isteri. ${ }^{5}$

Ketetapan atau peraturan yang mengatur tentang alasan-alasan perceraian di atas menunjukkan bahwa asas yang dipakai dalam hukum perkawinan yang berlaku di Indonesia adalah mempersulit terjadinya perceraian. Yang mana seseorang dapat becerai jika ada lasan yang tepat untuk bercerai, tanpa adanya alasan yang tepat untuk bercerai maka perceraian tidak dapat dilakukan. Perceraian hanya bisa dilakukan di depan sidang pengadilan. Maka jelaslah apa yang tertuang dalam Undang-undang perkawinan No.1 Tahun 1974 tentang Perkawinan, yang pada prinsipnya mempersukar serta melarang terjadinya perceraian.

\section{Pengertian Anak}

Pengertian anak menurut Undang-undang No.23 Tahun 2002 Jo Undang-undang No.35 Tahun 2014 Tentang Perlindungan anak, anak adalah seseorang yang belum berusia 18 (delapan belas) tahun, termasuk anak yang masih dalam kandungan. ${ }^{6}$ Sedangkan anak dalam Ensiklopedi hukum Islam didefinisikan sebagai orang yang lahir dalam rahim ibu, baik laki-laki maupun perempuan atau "khunsa" yang merupakan hasil persetubuhan dua lawan jenis. Menurut sumber ini, pengertian anak semata-mata

\footnotetext{
${ }^{4}$ Kompilasi Hukum Islam, Pasal 116.

${ }^{5}$ Hisako Nakamura, Perceraian Orang Jawa, alih bahsa H.Zaini Ahmad Noeh, (Yogyakarta: Gajahmada University Press, 1990), h.72.

${ }^{6}$. Undang-undang No.23 Tahun 2002 Jo Undang-undang No.35 Tahun 2014 Tentang Perlindungan anak
} 


\section{Perceraian Orang Tua dan Implikasinya Terhadap Pendidikan Anak Dalam Islam Rima Hadayati}

dinisbatkan pada konteks kelahiran dan posisinya sebagai seorang laki-laki atau perempuan. Al-Qur'an sendiri mendifinikan anak dengan istilah sebagai berikut :

\section{Al-Walad}

Al-Qur'an sering mengunakan kata "al-walad" untuk menyebut anak. Kata "alwalad" dengan segala bentuk derivasinya terulang Al-Qur'an sebanyak 65 kali, Dalam bahasa Arab kata "al-walad" berarti anak yang dilahirkan oleh orang tuanya, baik berjenis kelamin laki-laki maupun perempuan, besar atau kecil, baik untuk "mufrad" (tunggal), "tatsniyah"(dua)"jama" (banyak), anak yang belum lahir, berarti ia belum dpat disebut sebagai "al-walad" atau "al-mawdud", melainkan "al-janin", yang secara etimologis terambil dari kata "janna-yajunnu", berarti "al-matsur" dan "al-khafy" yakni sesuatu yang tertutup dari tersembunyi (dalam rahim ibu). Dalam al-Qur'an, kata "walad" dipakai untuk menggambarkan adanya hubungan keturunan,sehingga kata "walid", berarti ayah kandung, demikian pula kata "walidah" (ibu kandung) Ini berbeda dengan kata "ibn", yang tidak mesti menunjukkan hubungan keturunan. Jadi, "ibn" bisa berarti anak kandung dan anak angkat. Demikian pula kata " $a b$ " (bapak), bisa berarti ayah kandung dan ayah angkat.

\section{Ibn}

Al Qur'anjuga menggunakan kata “ibn" untuk menyebut anak. Kata “ibn” ini dengan segala bentuk derivasinya terulang sampai 161 kali. Lafaz $i^{\text {“' } i b n " ~ m e n u n j u k ~ p a d a ~}$ pengertian anak laki-laki yang tidak ada hubungan "nasab", yakni anak angkat, contohnya adalah pernyataan tradisi orang-orang Jahiliyah yang menisbatkan anak angkatnya seolah-olah seperti anaknya sendiri, sehingga anak angkat itu berhak untuk mewarisi hartanya, tidak boleh dinikahi dan sebagainya.

\section{3. bint.}

Dalam Al-Qur'an ketika disebut "bint" jamaknya "banat", berarti merujuk pada pengertian anak perempuan. Kata tersebut dengan berbagai macam bentuknya, terulang dalam Al Qur'ansebanyak 19 (sembilan belas) kali. Sehubungan dengan anak perempuan, Al-Qur'an memberikan informasi tentang bagaimana orang-orang jahiliyah memandang dan memperlakukan anak perempuan. Misalnya, mereka menganggap anak perempuan sebagai "aib" keluarga sehingga mereka pun tega mengubur anak perempuan mereka dalam keadaan hidup-hidup. Al-Qur'an mengecam tindakan tersebut sebagai kejahatan, dosa besar dan kebodohan (Q,S al Nahl 58-59). Lebih parah lagi, orang-orang Jahiliyah juga menisbatkan anak-anak perempuan untuk Allah, sementara mereka sendiri lebih memilih anak-anak laki-laki (Q.S al Thur 39 dan al Nahl 57). Padahal sesunguhnya Allah SWT tidak memiliki anak, karena Dia Esa, tidak beranak dan tidak pula diperanakkan (Q.S. al-Ikhlas: 1-4).

\section{Dzurriyyah}

Al-Qur'an juga menggunakan kata "dzurriyyah" untuk menyebut anak cucu atau keturunan. Kata tersebut terulang dalam Al-Qur'an sampai 32 (tiga puluh dua) kali. 
P-ISSN : 2541-3686

Sebagian besar ayatnya berkaitan dengan masalah harapan atau doa orangtua untuk memperoleh anak keturunan yang baik. Sebagian lagi berkaitan dengan peringatan Allah agar jangan sampai meninggalkan anak-anak yang bermasalah, sebagian lagi berkaitan dengan masalah balasan yang akan diterima oleh orangtua yang memiliki anak-anak yang tetap kokoh dalam keimanannya.

\section{Hafadah}

Dalam Al Qur'an, term "hafadah" bentuk jamak dari "hafid", dipakai untuk menunjukkan pengertian cucu (al-asbath) baik untuk cucu yang masih hubungan kerabat atau orang lain.Kata tersebut merupakan derivasi dari kata "hafada" yang berarti berkhidmah (melayani) dengan cepat dan tulus. Ini memberikan isyarat bahwa anak cucu sudah semestinya dapat berkhidmat kepada orangtuanya secara tulus, mengingat orangtualah yang menjadi sebab bagi anak dan cucu terlahir ke dunia.

\section{6. al-Shabiy}

Kata tersebut terulang dua kali dalam al-Qur'an, yaitu: Pertama, pada surat Maryam ayat 12. Kata al-Shabiyyu dalam ayat tersebut berarti kanak-kanak. Ayat itu memberikan informasi bahwa Allah memberikan menyuruh mempelajari kitab Taurat kepada Yahya dan memberinya hikmah (pemahaman atas kitab Taurat dan pendalaman agama), pada waktu Yahya masih kanak-kanak dan belum baligh. Demikian kurang lebih penjelasan al-Thabari, sebagaimana dikutip oleh Ali Al Shabuni dalam kitab Shafwatu al-Tafasir. Kedua, pada ayat 29 surat Maryam. Kata Shabiyyan pada ayat tersebut menunjuk pada pengertian anak yang masih dalam ayunan. Ketika itu Nabi Isa disuruh ibunya berbicara dan menjelaskan tentang hal keadannya (yakni hamil dan punya anak tanpa suami) kepada orang Yahudi, ia masih dalam keadaan menetek ibunya, ketika mendengar perintah ibunya, ia lalu melepaskan puting susu ibunya dan berbicara bahwa sesungguhnya saya (Isa) adalah hamba Allah yang diciptakan tanpa ayah.

\section{7. al-Thifl}

Kata "thifl" bentuk jamaknya "athfal" dalam Al-Qur'an terulang sebanyak empat kali, yaitu Q.S al-Nur: 31 dan 59, al-Hajj:5, al-Mukmin: 67. Kata "thifl" mengandung arti anak yang di dalam ayat-ayat tersebut tersirat fase perkembangannya. Dalam fase perkembangan anak itulah orang tua perlu mencermati dengan baik, bagaimana perkembangan anak-anak mereka. Sehingga jika ada gejala-gejala yang kurang baik (misalnya gejala autis), maka dapat diberikan terapi sebelum terlambat. Semakin baik orangtua memperhatikan masa perkembangan anaknya, maka Isnya Allah akan semakin baik pula hasil out putnya.

\section{8. al-Ghulam}

Sedangkan kata al-ghulam dalam berbagai bentukanya diulang 13 ali dalam alQur'an, yaitu Ali Imran :40, Yusuf 19, al-Hijr 53, al Kahfi 80 Maryam 7, 8 dan 20 , al- 


\section{Perceraian Orang Tua dan Implikasinya Terhadap Pendidikan Anak Dalam Islam Rima Hadayati}

Shaffat 101 dan al Dzariyat: 28. Kata ghulam berarti seorang anak muda, yang diperkirakan umurnya 14-21 tahun. Pada fase tersebut perhatian orang tua harus lebih cermat. Sebab pada itulah mereka biasanya mengalami puber, krisis identitas, dan bahkan perubahan yang luar biasa.

Beragam definisi anak yang diuraikan di atas, memberikan isyarat bahwa betapa $\mathrm{Al}$ Qur'ansangat memperhatikan kondisi social anak, baik yang menyangkut kedudukan anak, proses pendidikan dan pemeliharaan anak, hak-hak anak, hukum-hukum yang terkait dengan anak, maupun cara berinteraksi yang baik.

\section{Pendidikan Anak}

Pendidikan adalah suatu perkembangan dan kelengkapan dsri kemampuankemampuan manusia baik moral, intelektual, maupun jasmaniah yang diorganisasikan dengan atau untuk kepentingan intelektual, maupun jasmaniah yang diorganisasikan dengan atau untuk kepentingan individu dan diarahkan kepada kegiatan-kegiatan yang bersatu dengan penciptanya sebagai tujuan akhir. ${ }^{7}$

Adapun unsur-unsur yang terdapat dalam pendidikan antara lain:

a. Usaha (kegiatan), usaha ini bersifat bimbingan (pimpinan atau pertolongan dan dilaksanakan secara sadar

b. Ada pendidik, pembimbing, atau penolong

c. Ada yang dididik

d. Bimbingan itu mempunyai dasar dan tujuan

e. Dalam usaha itu tentu ada alat-alat yang diperlukan. ${ }^{8}$

Pendidikan menurut Islam adalah keseluruhan pengertian yang terkandung didalam istilah ta'lim, tarbiyah dan ta'dib. ${ }^{9}$ Definisi ini secara lengkap dijelaskan syech Muhammad al-Naquib al-Attas sebagai berikut; (1) ta'dib adalah yang paling tepat digunakan untuk mengembangkan pengertian pendidikan dalam Islam. Sedangkan istilah ta'lim terlalu sempit karena hanya menunjuk pengertian pengajaran. Adapun istilah tarbiyah terlalu luas karena istilah ini juga mencakup pengertian untuk hewan. ${ }^{10}$ Dijelaskan pula dalam bahwa " $t a$ ' $d i b$ " merupakan kata kerja "addaba" yang berarti pendidikan. ${ }^{11}$ Dari kata "addaba" ini muncul kata "addabim" yang berarti pengenalan dan pengakuan tentang hakikat bahwa pengetahuan tentang hakikat bahwa pengetahuan dan wujud bersifat teratur secara hierakis sesuai dengan berbagai tingkat dan derajat tingkatan mereka serta tempat seseorang yang tepat dalam hubungannya dengan itu serta dengan kapasitas yang potensi jasmaniah, intelektual maupun rohaniah seseorang.

Tujuan pendidikan Islam adalah sebagai kekuatan yang dapat membantu masyarakat mencapai kemegahan dan kemajuan peradaban. Tidak ada prestasi tanpa

\footnotetext{
${ }^{7}$ Akmal Nawi, Tantangan pendidikan Islam di Era Globalisasi, (Palembang: P3RF, 2007), h.79

${ }^{8}$ Hasbullah, Dasar-dasar Ilmu Pendidikan, (Jakarta: Rajawali Pers, 2009), h.3-4.

${ }^{9}$ King Abdul Aziz University, First World Conferse on Muslim Education Reccomendations, (Jeddah \& Mecca Al-Munawarah: King Abdul Aziz University, 1997), h.15.

${ }^{10}$ Syed Muhammad al-Naquib al-Attas, Konsep Pendidikan dalam Islam. Diterjemahkan oleh Haidar Bagir, (Bandung: Mizan, 1984), h. 52.

${ }^{11}$ Ibid., h.35.
} 
P-ISSN : 2541-3686

peranan pendidikan. Kejayaan Islam dibidang ekonomi, politik, intelektualisme, tradisitradisi keagamaan, seni dan sebagainya, tidak terlepas dari dunia pendidikan. Begitu pila dengan kemunduran pendidikan Isla, telah membawa Islam larut dalam kemunduran.

Penerapan pendidikan Islam harus diwujudkan dalam upaya untuk pengembangan potensi kepribadian manusia yang meliputi;:

1. Pengembangan iman dantaqwa kepada Allah SWT, menghasilakan kesucian

2. Pengembangan cipta menghasilkan ketentuan

3. Pengembangan karsa menghasilkan kebaikan

4. Pengembangan rasa menghasilkan keindahan

5. Pengembangan karya menghasilakn kegunaan

6. Pengembangan hati nurani menghasilkan kebijaksanaan. ${ }^{12}$

\section{Pengaruh Perceraian Terhadap Pendidikan Anak Dalam Keluarga}

Anak merupakan amanah dari Allah SWT, sebagai amanat, ia harus dipelihara, diberi bekal hidup, dan dididik agar kelak menjadi manusia yang dewasa secara fisik dan mental. Ia berhak memperoleh perlindungan dari semua orang, dan terhindar dari yang dapat menghambat, apalagi merusak perkembangannya secara jasmani maupun rohani. Orang tua dan masyarakat berhak memberikan perlindungan tersebut; ibunya misalnya wajib menyusuinya selama 2 tahun dan menjaga kesehatan dengan memberikan makanan bergizi, sedangkan masyarakat wajib menyiapkan sarana pendidikan untuknya. ${ }^{13}$

Anak-anak sangat membutuhkan kehadiran orang tuanya. Ia sangat membutuhkan seorang ayah yang memberinya nafkah, perlindungan dan pendidikan. Ia membutuhkan seorang ibu yang akan merawat, memperhatikan dan mengayominya. Anak yang sehat psikologisnya dan fisiknya adalah anak yang berkembang dalam keluarga utuh, tak bercerai berai, terjalinnya interaksi diantara anggota keluarganya dengan cinta dan kasih sayang, yang masing-masing anggotanya memperhatikan perasaan anggota yang lain.

Berbeda dengan orang dewasa anak belum bisa berfikir secara abstrak dan belum bisa mengenali dirinya sendiri. Ia peka terhadap gangguan kesehatan fisik atau kecelakaan serta terhadap masalah psikis (jiwa). Perilakunya juga belum stabil. Perkembangan kepribadian anak dipengaruhi lingkungan yang paling berpengaruh bagi perkembangan kepribadian anak adalah keluarga. Keluarga merupakan unit terkecil yang memberi fungsi fundamental bagi perkembangan anak, juga memberi pengaruh yang menentukan bagi pembentukan watak dan kepribadian anak, maka baik buruknya keluarga memberikan dampak pada pertumbuhan anak menuju kepada kedewasaan. Pengalaman berinteraksi dalam keluarga turut menentukan cara-cara berprilaku terhadap orang lain, apabila interaksi dalam keluarga tidak wajar karena beberapa sebab kemungkinan besar interaksi dengan masyarakat sekitarnya dan masyarakat pada umumnya juga berlangsung tidak wajar.

${ }^{12}$ Abdurrahman Al-Nahlawi, , Ushul al-Tarbiyah al-Islamiyah wa Asalibuh fi al-Bayt wa al-Madrasah wa al-Mustama’ , (Damaskus: Dar al-Fikr, 19790, h.4.

${ }^{13}$ Ensiklopedi Islam, Jilid 1, (Jakarta: Ichtiar Baru Van Hoeve, 2005), H.117. 


\section{Perceraian Orang Tua dan Implikasinya Terhadap Pendidikan Anak Dalam Islam Rima Hadayati}

Dalam hal terjadinya perceraian orang tua maka hak asuh anak dalam Kompilasi Hukum Islam (KHI), pasal 105: sebagai berikut:

a. Pemeliharaan anak yang belum mumayiz atau belum 12 tahun adalah ibunya

b. Pemeliharaan anak yang sudah mumayis diserahkan kepada anak untuk memilih di antara ayah dan ibunya sebagai pemegang hak pemeliharaannya

c. Biaya pemeliharaan ditanggung ayahnya ${ }^{14}$

Percerain apapun alasannya berdampak buruk bagi pertumbuhan dan perkembangan anak dan berpengaruh besar terhadap pendidikannya, sehingga biasanya anak-anak adalah pihak yang paling menderita dengan terjadinya perceraian orang tuanya Anak tidak akan dapat lagi menikmati kasih sayang orang tua secara bersamaan yang sangat penting bagi pertumbuhan mentalnya, tidak jarang pecahnya rumah tangga mengakibatkan terlantarnya pengasuhan anak. Itulah sebabnya dalam ajaran Islam perceraian harus dihindarkan sedapat mungkin bahkan merupakan perbuatan yang paling dibenci Allah SWT.

Sebagai akibat bentuk pengabaian tersebut, anak menjadi bingung, resah, risau, malu, sedih, sering diliputi perasaan dendam, benci, sehingga anak menjadi kacau dan liar. Dikemudian hari mereka mencari kompensasi bagi kerisauan batin sendiri diluar lingkungan keluarga, yaitu menjadi anggota dari suatu gang kriminal; lalu melakukan banyak tindakkan amoral dan kriminal. Pelanggaran kesetiaan loyalitas terhadap patner hidup, pemutusan tali perkawinan, ketidak teraturan dalam keluarga. Semua ini juga memunculkan kecenderungan menjadi timpang pada anak-anak dan remaja. Setiap perubahan dalam relasi personal antara suami-istri menjurus pada arah konflik dan perceraian. Maka perceraian merupakan faktor penentu bagi pemunculan kasus-kasus neurotik, tingkah laku a-susila, dan kebiasaan delinkuen (tindakkan tak terpuji).

Penolakan oleh orang tua atau ditinggalkan oleh salah seorang dari kedua orang tuanya, jelas menimbulkan emosi, dendam, rasa tidak percaya karena merasa dikhianati, kemarahan dan kebencian, sentimen hebat itu menghambat perkembangan relasi manusiawi anak. Muncullah kemudian disharmonis sosial dan lenyapnya kontrol diri, sehingga anak dengan mudah dapat dibawa ke arus yang buruk, lalu menjadi kriminal. Anak ini memang sadar, tetapi mengembangkan kesadaran yang salah. Fakta menunjukkan bahwa tingkah laku yang jahat tidak terbatas pada strata sosial bawah, dan strata ekonomi rendah saja tetapi juga muncul pada semua kelas, khususnya dikalangan keluarga yang berantakan. Memang perceraian suami-istri dan perpisahan tidak selalu mengakibatkan kasus delinkuen dan karakter pada diri anak.

Di antara dampak negatif dari kasus perceraian terhadap pendidikan dan perkembangan anak sebagai berikut:

1. Anak kurang mendapatkan perhatian, kasih sayang, dan tuntutan pendidikan orang tua, terutama bimbingan ayah, karena ayah dan ibunya masing-masing sibuk mengurusi permasalahan mereka.

2. Kebutuhan fisik maupun psikis anak menjadi tidak terpenuhi, keinginan harapan anak-anak tidak tersalur dengan sesuai, atau tidak mendapatkan kompensasinya.

\footnotetext{
${ }^{14}$ Kompilasi Hukum Islam, Pasal 105.
} 
P-ISSN : 2541-3686

3. Anak-anak tidak mendapatkan latihan fisik dan mental yang sangat diperlukan untuk hidup susila. Mereka tidak dibiasakan untuk disiplin dan kontrol diri yang baik.

4. Perceraian orang tua diperkirakan mempengaruhi prestasi belajar anak, baik dalam bidang studi agama maupun dalam bidang yang lain. Salah satu fungsi dan tanggung jawab orang tua yang mendasar terhadap anak adalah memperhatikan pendidikannya dengan serius. Memperhatikan pendidikan anak, bukan hanya sebatas memenuhi perlengkapan belajar anak atau biaya yang dibutuhkan, melainkan yang terpenting adalah memberikan bimbingan dan pengarahan serta motivasi kepada anak, agar anak berprestasi dalam belajar. Oleh karena itu kedua orang tua bertanggungjawab dalam memperhatikan pendidikan anak, baik perlengkapan kebutuhan sekolah atau belajar maupun dalam kegiatan belajar anak. jika orang tua bercerai maka perhatian terhadap pendidikan anak akan terabaikan.

5. Apabila anak diasuh oleh ayahnya atau ibunya, kemudian ayah atau ibunya tersebut menikah lagi dan disibukan dengan keluarga barunya maka anak bisa saja dalam hal pendidikan dia terabaikan seperti apabila anaknya ingin masih ingin sekolah tetapi orang tua tidak bisa membiayai dikarenakan banyak biaya yang harus dikeluarkan untuk keluarga barunya.

6. Menurut Sanchez perceraian dapat meningkatkan kenakalan anak-anak, meningkatkan jumlah anak-anak yang mengalami gangguan emosional dan mental, penyalahgunaan obat bius dan alkohol di kalangan anak-anak belasan tahun serta anak-anak perempuan muda yang menjadi ibu diluar nikah.

7. Mempengaruhi pembentukan kepribadian anak

Selain itu dampak perceraian bagi anak, antara lain:

1). Kesehatan Fisik

Anak dari keluarga bercerai memiliki fungsi fisik yang lebih lemah, hal ini dapat disebabkan oleh sumber keuangan yang diterima anak menjadi lebih sedikit, sehingga dapat berpengaruh terhadap ketersediaan dana kesehatan untuk anak. Selain itu, hasil riset lain menunjukkan bahwa setelah 10 tahun memantau kehidupan anak dari keluarga bercerai, mereka memiliki kesehatan fisik yang lebih buruk daripada anak dari keluarga utuh. Sehingga anak dari keluarga bercerai memiliki resiko yang lebih tinggi mendapatkan perawatan medis atau pengobatan.

\section{2) Kesejahteraan Psikologis/ mental}

Khususnya para remaja yang mengalami perceraian orang tua, mereka akan memiliki kesejahteraan psikologis dan penerimaan sosial yang lebih rendah daripada anak dari keluarga utuh. Hal ini dapat terjadi karena mereka tidak mendapatkan kasih sayang utuh dari kedua orang tua sehingga merasa kesejahteraan psikologisnya tidak terpenuhi. Pada akhirnya mereka mengalami kesulitan dalam menyesuaikan kondisi psikologisnya.

3) Kebebasan diri 


\section{Perceraian Orang Tua dan Implikasinya Terhadap Pendidikan Anak Dalam Islam Rima Hadayati}

Anak dari keluarga bercerai memiliki kebebasan yang lebih sedikit untuk mengatur dirinya. Hal ini dikarenakan anak dari keluarga bercerai memiliki permasalahan yang lebih kompleks daripada anak dari keluarga utuh. Adanya permasalahan yang dihadapi oleh anak dapat berpengaruh terhadap aktivitas atau kegiatan yang akan dilakukan.

\section{4) Suasana hati (mood) dan emosi}

Ketidakstabilan suasana hati dan emosi merupakan salah satu dampak jangka pendek yang ditimbulkan akibat dari perceraian orang tua. Anak akan merasakan berbagai macam emosi sebelum proses perceraian, selama proses perceraian dan setelah proses perceraian berakhir. Kondisi ini akan terus berlanjut dirasakan oleh anak dalam jangka waktu yang panjang setelah terjadinya perceraian orang tua.

5) Hubungan dengan orang tua dan kehiduan dirumah

Efek dasar dari perceraian (dan permasalahan orang tua yang menyebabkan perceraian) adalah melemahnya hubungan antara orang tua dan anak. Setelah terjadinya perceraian, orang tua memiliki dua kelompok masalah besar yaitu penyesuaian dengan konflik mereka sendiri dan peran mereka sebagai orang tua yang bercerai. Stres akibat dari perceraian dapat merusak hubungan antara orang tua dan anak. Selain itu, kesehatan mental ibu dan faktor sosial ekonomi dapat mengganggu hubungan antara orang tua dengan anak

\section{6) Lingkungan sekolah dan pembelajaran}

Akibat perceraian orang tua memiliki hubungan yang negatif dengan menurunnya prestasi akademik di sekolah. Anak memiliki cita-cita yang rendah dan hasil ujian yang rendah selama proses perceraian orang tua mereka berlangsung. Dalam riset lain menunjukkan bahwa anak dari keluarga bercerai memiliki kebiasaan membaca, mengeja dan menghitung yang lebih buruk. Selain itu, anak dari keluarga bercerai juga memiliki kebiasaan absen di kelas $60 \%$ lebih banyak daripada anak dari keluarga utuh.

\section{Simpulan}

Setiap anak pada dasarnya ingin mempunyai keluarga yang utuh dan mendapat kasih sayang orang tuanya secara penuh. Tetapi apabila rumah tangga kedua orang tuanya tidak bisa didamaikan dan berakhir dengan perceraian maka anak menjadi korban. Dampak perceraian orang tua terhadap pendidikan anak antara lain: kurangnya perhatian orang tua terhadap pendidikan anak, anak menjadi malas (tidak mau bersekolah) karena beban psikologi yang dialami, seperti: dia masih merasa kehilangan ayah atau ibunya, di sekolah atau dilingkungannya dia diejek teman-temanya, selain anak masih ingin sekolah tetapi orang tua tidak sanggup membiayai dikarenakan penghasilan orang tua difokuskan untuk membiayai keluarga barunya. Akibatnya anak menjadi putus sekolah.nak yang putus sekolah berakibat anak menjadi nakal, pergaulan anak menjadi bebas, akhlaknya menjadi kurang baik. 
RAUDHAH Proud To Be Professionals Jurnal Tarbiyah)damiyah

Volume 1 Nomor 1 Edisi Juni 2016

P-ISSN : 2541-3686

\section{DAFTAR PUSTAKA}

Al-Nahlawi, Abdurrahman. 1979. Ushul al-Tarbiyah al-Islamiyah wa Asalibuh fi al-Bayt wa alMadrasah wa al-Mustama', Damaskus: Dar al-Fikr.

Al-Naquib al-Attas, Syed Muhammad. 1984. Konsep Pendidikan dalam Islam.,Diterjemahkan oleh Haidar Bagir, Bandung: Mizan.

Akmal Nawi. 2007. Tantangan pendidikan Islam di Era Globalisasi, Palembang: P3RF.

Hasbullah. 2009. Dasar-dasar Ilmu Pendidikan, Jakarta: Rajawali Pers.

Hamid, Zahri . 1976. Pokok-pokok Hukum Perkawinan Islam dan Undang-undang Perkawinan Indonesia, Yogyakarta: Bina Cipta

King Abdul Aziz University, First World Conferse on Muslim Education Reccomendations, (Jeddah \& Mecca Al-Munawarah: King Abdul Aziz University, 1997), h.15.

Nakamura, Hisako, 1990.Perceraian Orang Jawa, alih bahasa H.Zaini Ahmad Noeh, Yogyakarta: Gajahmada University Press

Sopiah, Dwi Istiyani, Nur Khasanah, Perempuan dan Pendidikan Tinggi, Pekalongan, STAIN Press, 2014.

Ensiklopedi Islam, Jilid 1, Jakarta: Ichtiar Baru Van Hoeve, 2005.

Undang-undang No.23 Tahun 2002 Jo Undang-undang No.35 Tahun 2014 Tentang Perlindungan anak

Undang-undang No.1 Tahun 1974 Tentang Perkawinan

Kompilasi Hukum Islam 